\title{
Scholarly

\section{Different Dietary Levels of Protein to Lipid Ratio Affected Digestive Efficiency, Skeletal Growth, and Muscle Protein in Rainbow Trout Families}

\author{
Krisna Rungruangsak-Torrissen, ${ }^{1}$ Lars H. Stien, ${ }^{1,2,3}$ Britt S. Daae, ${ }^{1}$ Tone Vågseth, ${ }^{1}$ Grethe B. \\ Thorsheim, ${ }^{1}$ Declan Tobin, ${ }^{4}$ and Ossi Ritola ${ }^{5}$
}

${ }^{1}$ Institute of Marine Research, Matre Research Station, 5984 Matredal, Norway

${ }^{2}$ Department of Biology, University of Bergen, P.O. Box 7800, 5020 Bergen, Norway

${ }^{3}$ Institute of Marine Research, P.O. Box 1870 Nordnes, 5817 Bergen, Norway

${ }^{4}$ School of Biological Sciences, Department of Zoology, University of Aberdeen, Aberdeen AB24 2TZ, UK

${ }^{5}$ Finnish Game and Fisheries Research Institute, Tervo Fisheries Research and Aquaculture, 72210 Tervo, Finland

Correspondence should be addressed to Krisna Rungruangsak-Torrissen, Krisnart@imr.no

Received 13 November 2008; Revised 31 March 2009; Accepted 15 April 2009

\begin{abstract}
Normal Protein (NP) and High Protein (HP) diets were provided to rainbow trout families from juvenile to maturity. Muscle protein concentration increased during growth and the protein to lipid $(\mathrm{P} / \mathrm{L})$ ratio was doubled at late stage with respect to the dietary P/L ratio. The HP-diet fish showed higher protein deposition in body and white muscle, and had lower condition factor due to protein deposition associated more with body length than body weight. Fish growth rates were decreased at maturation, and the HP-diet fish showed lower growth rate including the activity ratio of trypsin to chymotrypsin (T/C ratio) and feed efficiency. Trypsin and chymotrypsin specific activities were related to dietary protein levels, and the T/C ratio was related to intestinal weight and growth rate independent of the enzymes specific activity levels. The families with high growth capacity could double increase white muscle P/L ratio levels, compared to low and medium growth families, if they were fed on HP-diet. The digestive enzyme extracts from high growth families resulted in higher in vitro protein digestibility for all diets. The effect of dietary P/L ratio on digestion, skeletal growth (length) and the white muscle P/L ratio in fish with different growth capacities is illustrated.
\end{abstract}

Copyright (C) 2009 Krisna Rungruangsak-Torrissen et al. This is an open access article distributed under the Creative Commons Attribution License, which permits unrestricted use, distribution, and reproduction in any medium, provided the original work is properly cited.

\section{Introduction}

One of the principal goals in contemporary aquaculture is the dual optimisation of growth efficiency and protein content through a process of selective culture. The growth efficiency of several fish species has been studied through variation of dietary protein levels, and the results have shown not only the relationships between dietary protein concentration and physiological parameters of consumption, growth, and protein content in body or muscle, but also shown certain increased levels of dietary protein limited consumption and growth of the fish recently, that is, [19]. Increased growth is usually not associated with an increase in protein deposition rate, that is, [10-12], but rather an increase in lipid deposition rate, that is, $[8,13]$. Traditionally in aquaculture, dietary protein and lipid are varied throughout the life cycle to optimise the economic return. In the current work, we aim to understand a basic knowledge on long-term protein growth by investigating the effects of maintaining dietary protein and lipid concentrations throughout the fish life cycle on digestive efficiency and protein growth using a unique combination of techniques recently described by Rungruangsak-Torrissen's research team $[11,12,14]$. In addition, we also aim to study the potential for maximising protein growth efficiency in rainbow trout (Oncorhynchus mykiss Walbaum) families with differences in growth capacity by varying the concentrations of dietary protein and lipid.

The current work was a part of a European Union project assessing the potential for genetic selection of protein and growth efficiency traits in salmonids. The work was performed in different families of rainbow trout divided into 
TABLE 1: Compositions on wet weight basis of the experimental diets, normal protein (NP) and high protein (HP) diets.

\begin{tabular}{|c|c|c|c|c|c|c|c|c|c|}
\hline $\begin{array}{l}\text { Experimental } \\
\text { diets }\end{array}$ & $\begin{array}{c}\text { Moisture } \\
{[\%]}\end{array}$ & $\begin{array}{c}\text { Crude } \\
\text { protein }(\mathrm{P}) \\
{[\%]}\end{array}$ & $\begin{array}{c}\text { Crude } \\
\text { lipid (L) } \\
{[\%]}\end{array}$ & $\mathrm{P} / \mathrm{L}$ ratio & $\begin{array}{c}\text { Crude fibre } \\
{[\%]}\end{array}$ & $\begin{array}{l}\text { Ash } \\
{[\%]}\end{array}$ & $\begin{array}{c}\text { Nitrogen } \\
\text { free extract } \\
{[\%]}\end{array}$ & $\begin{array}{c}\text { Phosphorus } \\
{[\%]}\end{array}$ & $\begin{array}{l}\text { Energy } \\
{\left[\mathrm{kJ} \mathrm{g}^{-1}\right]}\end{array}$ \\
\hline $\mathrm{NP}(3 \mathrm{~mm})$ & 2.1 & 44.9 & 30.5 & 1.5 & 0.73 & 7.4 & 15.1 & 1.21 & 23.6 \\
\hline $\mathrm{NP}(6 \mathrm{~mm})$ & 1.5 & 44.6 & 30.3 & 1.5 & 0.72 & 7.7 & 15.9 & 1.27 & 26.0 \\
\hline $\mathrm{NP}(7 \mathrm{~mm})$ & 4.0 & 39.5 & 33.4 & 1.2 & 1.00 & 6.7 & 15.4 & 0.96 & 25.9 \\
\hline $\mathrm{HP}(3 \mathrm{~mm})$ & 2.3 & 56.4 & 20.7 & 2.7 & 0.44 & 9.6 & 11.1 & 1.55 & 25.6 \\
\hline $\mathrm{HP}(6 \mathrm{~mm})$ & 1.7 & 56.3 & 20.6 & 2.7 & 0.48 & 9.5 & 11.9 & 1.54 & 24.0 \\
\hline HP (7 mm) & 7.2 & 49.4 & 23.8 & 2.1 & 1.30 & 8.3 & 10.0 & 1.18 & 23.3 \\
\hline
\end{tabular}

two groups fed on two levels of dietary protein to lipid $(\mathrm{P} / \mathrm{L})$ ratio during a two-year life span from juvenile to maturity, and subdivided according to differences in growth capacities. Feed intake was measured by X-ray method using diets labelled with radio-opaque markers [15]. The in vitro protein digestibility of formulated fish feeds was determined using fish crude enzyme extracts, as it has been correlated with the feed efficiency $[11,16]$ and the chemical properties of dietary proteins, positively with the levels of reactive sulphydryl group and negatively with the levels of disulphide bond and $D$-aspartic acid [16]. Fish digestive efficiency [trypsin specific activity and the protease activity ratio of trypsin to chymotrypsin (T/C ratio)] was measured because of their known positive associations with fish growth rate $[10-12,14,17,18]$. The effects of dietary protein and P/L ratio levels on the protein and lipid compositions as well as the $\mathrm{P} / \mathrm{L}$ ratios of the body and white muscle were also determined. The $\mathrm{P} / \mathrm{L}$ ratio is important as both protein and lipid levels in the diets affect the levels of both protein and lipid in fish where the variations may not be observed if either protein or lipid level is studied alone. Although both protein and lipid deposition are important but the in vitro lipid digestibility was not determined because it has never been shown to associate with feed efficiency and the quality of the lipid itself [19], and in vitro protein digestibility is the key factor for feed quality even in the herbivore like mussel [19, 20]. This work was designed to illustrate the effects of dietary $\mathrm{P} / \mathrm{L}$ ratio levels on fish digestive ability and the quality of fish growth performance (condition factor and composition of $\mathrm{P} / \mathrm{L}$ ratio in the body and white muscle) in families of rainbow trout with different growth capacities throughout the life history. The digestive efficiency was studied at the end of the experiment at the late stage of life cycle. It is advantageous to use the different methods simultaneously, as they could precisely provide practical important biological informations between fish groups with differences in genetics (growth capacity) and environmental impacts (diet quality) that could not be explained by using growth parameter alone, especially when feeding regime were not completely under control see $[11,12,14]$.

\section{Materials and Methods}

2.1. Experimental Design. The experiment was performed on rainbow trout from an on-going selection programme at the Finnish Game and Fisheries Research Institute, Tervo, Finland. One-year old trout from 45 families selected were tagged with PIT-transponders (Trovan Inc., Germany) and equally distributed into eight $3 \mathrm{~m}^{3}$ tanks (340 fish per tank) at the end of January 2002. Further details of the genetic design of the experiment have been described [21, 22]. From hatching to the initiation of the experiment, all fish were fed commercial rainbow trout diets, Raisio Nutra Starter [52\% crude protein and $20 \%$ crude lipid (P/L ratio 2.6 )] and Raisio Nutra Parr [50\% crude protein and 23\% crude lipid (P/L ratio 2.2)] (Rehuraisio Inc., Finland) using automatic feeders. In May 2002, two diet treatments were initiated. Four tanks (average fish weight $141.2 \pm 2.2 \mathrm{~g}$ ) were provided an experimental normal protein (NP-) diet, and the other four (average fish weight $143.9 \pm 2.2 \mathrm{~g}$ ) were provided an experimental high protein (HP-) diet. The experimental NPand HP-diets were manufactured by Rehuraisio Inc., Finland. The diets were formulated using standard ingredients for rainbow trout in Finnish aquaculture, consisting of fish meal, fish oil, wheat meal, wheat starch, and supplemented for vitamins and minerals according to the National Research Council [23]. The compositions of the experimental diets are shown in Table 1. To avoid restricted growth, a slight over-feeding regime was applied. In June 2002, the fish were transferred to larger tanks $\left(20 \mathrm{~m}^{3}\right)$ and reared through until the end of the experiment in November 2003. Fish density was maintained below $20 \mathrm{~kg} \mathrm{~m}^{-3}$. Oxygen concentration in the water was maintained above $6 \mathrm{mg} \mathrm{L}^{-1}$. The fish experienced ambient seasonal temperature regimes during the experimental period, fluctuating from below $5^{\circ} \mathrm{C}$ during winters to around $20^{\circ} \mathrm{C}$ in summers. Individual fish weight and fork length were recorded in May and September 2002, and in May, September, and November 2003. Individual feed consumption was measured using the X-ray method [15] involving both NP- and HP-diets labelled with radioopaque markers (more details in [21]). Nine estimates of feed intake were calculated during the three-week X-ray sessions performed during May-June 2002, September-October 2002, and September 2003. Feed efficiency was estimated, as weight gained per weight dry feed consumed in each session, and averaged across all three sessions. To estimate white muscle and whole body compositions, samples were collected in November 2002 and November 2003.

Of the 45 families, 16 families were sorted with representatives of both diets available for each family selected. Three 
different growth capacity groups were divided, 6 families for high $(\mathrm{H}), 5$ families for medium $(\mathrm{M})$, and 5 families for low (L) growth capacity, based on the body weight measurements recorded in September 2003 (altogether 120 individuals). At the end of the experiment in November 2003, pyloric caeca samples were collected (3-5 fish per family per diet). Intestinal, gonad, and carcass weights were measured. In vitro protein digestibility of the experimental feeds and fish digestive efficiency were analysed, using the pyloric caecal enzyme extracts. Only these 120 fish were studied in the current work. As thermal growth coefficient [24] did not provide different interpretations from specific growth rate (SGR) in this experiment, the simple SGR was chosen and calculated [25]:

$$
\operatorname{SGR}\left(\% \operatorname{day}^{-1}\right)=100\left[e^{g}-1\right],
$$

where $g=\left(\ln W_{2}-\ln W_{1}\right) /\left(t_{2}-t_{1}\right)$, and $W_{2}=$ Weight at day $t_{2}, W_{1}=$ Weight at day $t_{1}$.

The condition factor was calculated [26]

$$
\text { Condition factor }=100 \times W / L^{3},
$$

where $W=$ Live body weight $(\mathrm{g})$ and $L=$ Body fork length (cm).

2.2. Determinations of White Muscle and Body Composition. About $10 \mathrm{~g}$ of epaxial white muscle was dissected from individual fish in November 2002 and November 2003. The remainder of the fish was used for determination of whole body composition. All tissue samples were stored at $-80^{\circ} \mathrm{C}$ and homogenised before analyses. The compositions of protein, lipid, and dry matter were estimated for the white muscle and whole body. The white muscle in November 2002 and the whole body samples in November 2003 were determined using FMA2001 Milk Analyser (Miris AB, Sweden) with mid-infrared transmittance, after homogenisation in standard solvent Mirasolve with Losmixer (Miris AB, Sweden). Due to later technical complications, the body composition in November 2002 and the white muscle composition in November 2003 were analysed using an INFRATEC Food \& Feed Analyser (Tecator, Sweden) with near-infrared transmittance. To calibrate between the methods, approximately 50 samples were coanalysed by both analysers (more details in [27]).

The results from INFRATEC Food \& Feed Analyser were estimated using The Unscrambler, software for multivariate data analysis (CAMO Process AS, Norway) with multiregression models standardised by the values from 50 white muscle samples and 50 whole body samples analysed chemically. The moisture content of the standards was determined by drying a known amount (about $3 \mathrm{~g}$ ) of homogenised sample at $105^{\circ} \mathrm{C}$ for 24 hours to constant weight. The lipid concentration was determined from the dry matter by extracting with $15 \mathrm{~mL}$ ethylacetate for 60 minutes on a mixing plate, and the lipid-ethylacetate extract was subsequently dried gradually at $65-105^{\circ} \mathrm{C}$, cooled in desiccator, and then weighed [20, 28-30]. The protein concentration of the standards was determined using TRIzol reagent (Life Technologies, NY, USA) to obtain complete solubilisation of protein, as described in RungruangsakTorrissen [11] modified from Sunde et al. [10, 18].

Protein deposition (protein growth) was expressed as the composition ratio of protein to lipid ( $\mathrm{P} / \mathrm{L}$ ratio) in the body and white muscle.

2.3. Determination of Digestive Efficiency. Pyloric caeca sampled from 120 individuals were analysed for trypsin specific activity and protease activity ratio of trypsin to chymotrypsin (T/C ratio), as indicators for digestive efficiency that have been related with fish growth rate [10$12,14,16,18]$. All samples were kept frozen at $-80^{\circ} \mathrm{C}$ prior to analyses. The samples were homogenised and the enzymes were extracted using $1 \mathrm{mM} \mathrm{HCl}$. After centrifugation at $15000 \times \mathrm{g}$ for 60 minutes at $4^{\circ} \mathrm{C}$, the supernatants were kept frozen at $-80^{\circ} \mathrm{C}$ until analyses. Trypsin and chymotrypsin activities were determined, using benzoyl- $L$ arginine- $p$-nitroanilide as trypsin substrate and $N$-succinylAla-Ala-Pro-Phe-p-nitroanilide as chymotrypsin substrate, according to Rungruangsak-Torrissen [11] based on Sunde et al. [10, 18] and Rungruangsak-Torrissen et al. [16]. The concentration of protein in the crude enzyme extract was determined by the Lowry method [31] using the BioRad DC (Detergent Compatible) Protein Assay (Bio-Rad Laboratories, Calif, USA). The enzyme specific activities were expressed as $\mu \mathrm{mol} p$-nitroaniline produced $\mathrm{h}^{-1} \mathrm{mg}_{\text {protein }}{ }^{-1}$. The protease activity ratio of trypsin to chymotrypsin (T/C ratio) was directly calculated from each individual, and the slope $\mathrm{T} / \mathrm{C}$ ratio was obtained from the regression between trypsin (y-axis) and chymotrypsin (x-axis) specific activities at each sampling period [32].

2.4. In Vitro Digestibility Study. The in vitro protein digestibility of experimental feeds was performed according to Rungruangsak-Torrissen [11], modified from Rungruangsak-Torrissen et al. [16] and Bassompierre et al. [33]. Due to limited amount of pyloric caecal sample collected from each fish, the pyloric caecal crude enzyme extracts were pooled per family per diet (16 samples for each diet) after determination of the trypsin and chymotrypsin specific activities in each individual. The pooled crude enzyme extracts were dialysed using a Pierce Slide-A-Lyzer Dialysis Cassette (Pierce Chemical Company, Ill, USA) and concentrated using an Amicon Ultra-15 centrifugal filter device $10 \mathrm{KNMWL}$ (Millipore Corporation, Mass, USA) before use. In vitro protein digestibility was measured in a commercial control (C) diet [Raisio Royal Response with $47 \%$ crude protein and $23 \%$ crude lipid (P/L ratio 2.0 ), Rehuraisio Inc., Finland] and the experimental NP (40\% crude protein with $\mathrm{P} / \mathrm{L}$ ratio 1.2$)$ and $\mathrm{HP}$ (49\% crude protein with $\mathrm{P} / \mathrm{L}$ ratio 2.1$)$ diets $(7 \mathrm{~mm}$, see Table 1$)$. In vitro protein digestibility of control C-diet, and experimental NP-diet and HP-diet were performed using crude enzyme extracts from the 16 families selected, divided into low $(n=34)$, medium $(n=36)$, and high $(n=41)$ growth capacity family groups.

Digestion of a known amount of feed (about $20 \mathrm{mg}$ in $40 \mathrm{~mL}$ of $50 \mathrm{mM}$ phosphate buffer $\mathrm{pH} 8.2$ and $0.2 \mathrm{~mL}$ 


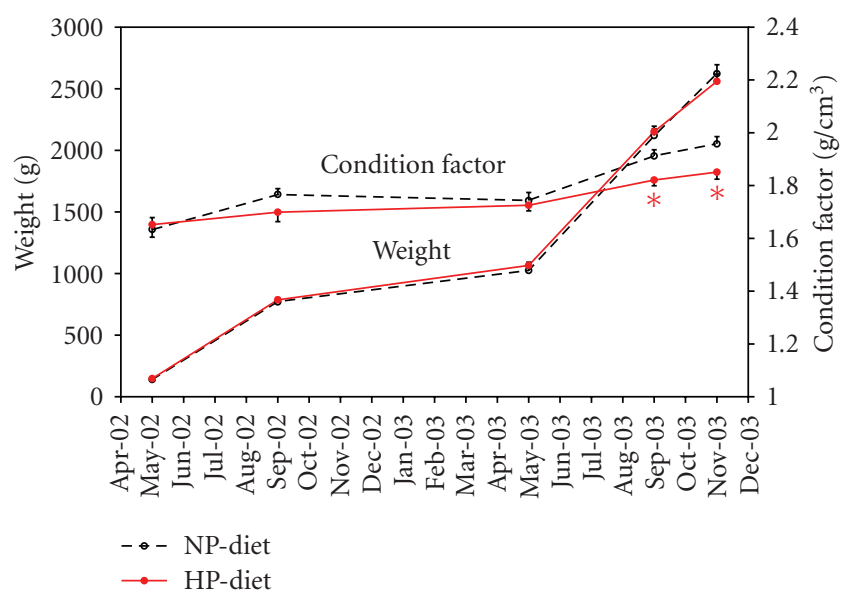

Figure 1: Weight and condition factor of rainbow trout fed normal protein (NP) and high protein (HP) diets during the entire experimental period. The values with asterisk $(*)$ are significantly different $(P<.05)$ between the dietary groups.

of $0.5 \%$ chloramphenicol) by enzyme extract $(0.5 \mathrm{~mL})$ was performed in triplicate at $15^{\circ} \mathrm{C}$ for 24 hours [11] for each diet and each dialysed pooled crude enzyme extract. The reactive amino groups of peptides produced after digestion were determined using the trinitrobenzene sulphonic acid (TNBS) assay and calculated using $D L$-alanine as a standard, as described in Rungruangsak-Torrissen [11], modified from Bassompierre et al. [33] based on Ihekoronye [34]. The in vitro protein digestibility value was expressed as $\mu \mathrm{mol} D L$ alanine equivalent liberated reactive amino group of cleaved peptides per mg feed sample after standardising trypsin activity in each dialysed pooled crude enzyme extract to $300 \mu \mathrm{mol} p$-nitroaniline produced $\mathrm{h}^{-1} \mathrm{~mL}^{-1}$.

2.5. Statistical Analysis. The statistical procedures were performed using the SAS software package (v. 8.02 for Windows, SAS Institute Inc., NC, USA). Relationships, on an individual basis, between different diets, families, and growth capacity groups were studied using the general linear model (glm) procedure. This analysis included individual continuous variables (covariates: e.g., white muscle $\mathrm{P} / \mathrm{L}$ ratio or SGR). In cases where class-by-covariate interaction was significant, the analysis was broken down and performed per class (e.g., per diet or per growth capacity group). All results are given as the least squares means \pm standard error. Differences between means were tested by $t$-test. The difference was set at $95 \%$ significance level.

\section{Results}

3.1. Fish Growth and Feed Efficiency. Due to some uncertain labelling, only 111 out of 120 fish were used for the analyses. Paired comparison indicated that the HP-diet fish had lower condition factor than the NP-diet fish during the entire experimental period $(P<.05$; Figure 1$)$. The differences in condition factor were enhanced during autumn to winter, especially the last period from September to November 2003
$(P<.01$; Figure 1 and Table 2$)$. This was due to differences in body length between the diet treatments $(P<.03$; Table 2$)$. There were no significant differences in body weight between the two dietary groups although the HP-diet fish seemed to have a relatively higher body weight than the NP-diet fish before maturation $(P>.05)$. During maturation in the last two months, fish growth rates were reduced in both dietary groups, and the HP-diet fish showed a higher decrease in SGR $(P<.001)$ with the body weight changed $(P>.05)$ from a relatively higher in September 2003 to a relatively lower in November 2003, compared to the NP-diet fish (Figure 1 and Table 2). The HP-diet fish also had lower feed efficiency (FE) than the NP-diet fish $(P<.05 ;$ Table 2$)$. Individual feed intake in September 2003 was not correlated with FE but showed a positive correlation with SGR during the last two months $\left(R^{2}=0.11, P<.05\right)$.

There were relationships between body weight and carcass weight, and between body weight and intestinal weight $\left(R^{2}=0.49-0.98, P<.0001\right)$. The relationships between SGR with carcass weight and between SGR with intestinal weight were also observed $\left(R^{2}=0.08-0.29, P<\right.$ $.0001)$. This was consistent for both dietary treatments. However, intestinal weight was lower in the HP-diet fish $(P<$ .0001; Table 2), due to reduction in lipid deposits around the intestine (observed visually). No differences in carcass and gonad weights (Table 2) were observed between the two dietary groups.

Maturation rate seemed to be higher in the HP-diet than the NP-diet fish in all growth capacity groups, varied from $64.7-84.2 \%$ in the HP-diet fish compared to $52.9-70.6 \%$ in the NP-diet fish.

3.2. Digestive Proteases in the Pyloric Caeca. At maturity in November 2003, rainbow trout fed on HP-diet had higher specific activities of the protease enzymes trypsin $(P<.02)$ and chymotrypsin $(P<.01)$, and lower T/C ratio $(P<$ .03 ), than those fed on NP-diet (Table 2). When the fish were grouped according to family growth capacity, the same trends were also observed within each growth capacity group, but the difference was only significant in the chymotrypsin specific activity between the fish fed HP- and NP-diets in the high growth capacity families $(P<.05$; Table 2$)$.

Trypsin $(P<.002$; Figure $2(a))$ and chymotrypsin $(P<$ .003 ; Figure 2(b)) specific activities were inversely correlated with the intestinal weight. In contrast, the T/C ratio was positively correlated with the intestinal weight $(P<.03$; Figure 2(c)). Similarly, the specific activities of trypsin $\left(R^{2}=\right.$ $0.05, P<.002)$ and chymotrypsin $\left(R^{2}=0.04, P<.05\right)$ were inversely correlated with body weight, and the $\mathrm{T} / \mathrm{C}$ ratio showed a trend of positive correlation with fish body weight although insignificant (data not shown). Among the protease parameters measured, only the specific activity of trypsin was inversely correlated with SGR $\left(R^{2}=0.04, P<.04\right)$ during maturation, regardless of dietary type (data not shown). Within each dietary group, these relationships were not significant, except for the negative correlation in the HP-diet group between intestinal weight and trypsin specific activity 
TABle 2: Different biological parameters in rainbow trout fed the experimental normal protein (NP) and high protein (HP) diets, in vitro protein digestibility was expressed as $\mu \mathrm{mol} D L$-alanine equivalent liberated reactive amino group of cleaved peptides per mg feed after standardising trypsin activity in each dialysed pooled crude enzyme extract to $300 \mu \mathrm{mol} p$-nitroaniline produced $\mathrm{h}^{-1} \mathrm{~mL}^{-1}$, and the values with asterisk $\left(^{*}\right)$ are significantly different $(P<.05)$.

\begin{tabular}{|c|c|c|}
\hline Parameters & NP-diet group $(n=56)$ & HP-diet group $(n=55)$ \\
\hline Initial weight in May $2002[\mathrm{~g}]$ & $140 \pm 5$ & $148 \pm 5$ \\
\hline \multicolumn{3}{|l|}{ September 2003} \\
\hline Weight $[\mathrm{g}]$ & $2120 \pm 55$ & $2151 \pm 44$ \\
\hline Length $[\mathrm{cm}]$ & $47.9 \pm 0.37^{*}$ & $49.0 \pm 0.34^{*}$ \\
\hline Condition factor $\left[\mathrm{g} \mathrm{cm}^{-3}\right]$ & $1.91 \pm 0.02^{*}$ & $1.82 \pm 0.02 *$ \\
\hline \multicolumn{3}{|l|}{ November 2003} \\
\hline Final weight $[\mathrm{g}]$ & $2622 \pm 73$ & $2560 \pm 60$ \\
\hline Final length $[\mathrm{cm}]$ & $51.0 \pm 0.4$ & $51.6 \pm 0.4$ \\
\hline Final condition factor $\left[\mathrm{gcm}^{-3}\right]$ & $1.96 \pm 0.03^{*}$ & $1.85 \pm 0.03^{*}$ \\
\hline Specific growth rate (Sept-Nov 2003) $\left[\%\right.$ day $\left.^{-1}\right]$ & $0.50 \pm 0.02^{*}$ & $0.40 \pm 0.02^{*}$ \\
\hline \multicolumn{3}{|l|}{ Feed efficiency [daily-gain in g per g feed-intake] } \\
\hline Average of all three X-ray sessions & $1.73 \pm 0.13^{*}$ & $1.31 \pm 0.09^{*}$ \\
\hline Trypsin specific activity $\left[\mu \mathrm{mol} p\right.$-nitroaniline $\left.\mathrm{h}^{-1} \mathrm{mg}_{\text {protein }}{ }^{-1}\right]$ & $28.7 \pm 2.2^{*}$ & $41.0 \pm 4.5^{*}$ \\
\hline low growth capacity group & $30.1 \pm 4.5(n=17)$ & $39.3 \pm 7.9(n=17)$ \\
\hline medium growth capacity group & $27.7 \pm 3.3(n=17)$ & $40.2 \pm 7.0(n=19)$ \\
\hline high growth capacity group & $28.3 \pm 3.7(n=22)$ & $43.4 \pm 8.8(n=19)$ \\
\hline Chymotrypsin specific activity $\left[\mu \mathrm{mol} p\right.$-nitroaniline $\left.\mathrm{h}^{-1} \mathrm{mg}_{\text {protein }}{ }^{-1}\right]$ & $102 \pm 9^{*}$ & $143 \pm 12^{*}$ \\
\hline Low growth capacity group & $108 \pm 19(n=17)$ & $139 \pm 20(n=17)$ \\
\hline Medium growth capacity group & $103 \pm 17(n=17)$ & $138 \pm 15(n=19)$ \\
\hline High growth capacity group & $96 \pm 13^{*}(n=22)$ & $151 \pm 24^{*}(n=19)$ \\
\hline Protease activity ratio of trypsin to chymotrypsin (T/C ratio) & $0.32 \pm 0.02^{*}$ & $0.27 \pm 0.01^{*}$ \\
\hline Low growth capacity group & $0.31 \pm 0.02(n=17)$ & $0.25 \pm 0.02(n=17)$ \\
\hline Medium growth capacity group & $0.33 \pm 0.04(n=17)$ & $0.28 \pm 0.03(n=19)$ \\
\hline High growth capacity group & $0.32 \pm 0.03(n=22)$ & $0.29 \pm 0.03(n=19)$ \\
\hline \multicolumn{3}{|l|}{ In vitro digestibility $\left[\mu \mathrm{mol} D L\right.$-alanine equivalent $\left.\mathrm{mg} \mathrm{feed}^{-1}\right]$} \\
\hline Control diet & $4.25 \pm 0.45(n=16)$ & $4.61 \pm 0.69(n=16)$ \\
\hline NP-diet & $4.24 \pm 0.45(n=16)$ & $4.80 \pm 0.75(n=16)$ \\
\hline HP-diet & $4.92 \pm 0.48(n=16)$ & $5.49 \pm 0.80(n=16)$ \\
\hline \multicolumn{3}{|l|}{ In vitro digestibility regardless of diet type } \\
\hline Low growth capacity group & $4.32 \pm 0.44(n=15)$ & $3.85 \pm 0.48(n=15)$ \\
\hline Medium growth capacity group & $4.17 \pm 0.39(n=15)$ & $3.91 \pm 0.43(n=15)$ \\
\hline High growth capacity group $(P<.06)$ & $4.85 \pm 0.37(n=18)$ & $6.77 \pm 0.49(n=18)$ \\
\hline Intestinal weight $[\mathrm{g}]$ & $340 \pm 12^{*}$ & $279 \pm 9^{*}$ \\
\hline Gonad weight $[\mathrm{g}]$ & $60 \pm 7$ & $72 \pm 7$ \\
\hline Carcass weight $[\mathrm{g}]$ & $2191 \pm 60$ & $2196 \pm 50$ \\
\hline \multicolumn{3}{|l|}{ Proximate composition [\% on wet weight basis] } \\
\hline Muscle protein & $22.9 \pm 0.4^{*}$ & $24.8 \pm 0.4^{*}$ \\
\hline Muscle lipid & $8.6 \pm 0.3^{*}$ & $6.3 \pm 0.3^{*}$ \\
\hline Muscle ratio of protein to lipid ( $\mathrm{P} / \mathrm{L}$ ratio) & $2.92 \pm 0.14^{*}$ & $4.44 \pm 0.22^{*}$ \\
\hline Body protein & $15.7 \pm 0.07^{*}$ & $16.4 \pm 0.07^{*}$ \\
\hline Body lipid & $22.1 \pm 0.17^{*}$ & $20.2 \pm 0.19^{*}$ \\
\hline Body ratio of protein to lipid ( $\mathrm{P} / \mathrm{L}$ ratio) & $0.71 \pm 0.01^{*}$ & $0.82 \pm 0.01^{*}$ \\
\hline
\end{tabular}

$(P<.03$; Figure 2(a) $)$ and between final weight and trypsin specific activity $\left(R^{2}=0.09, P<.03\right)$. The observations of similarity in slope T/C ratio (Figure 3 ) between the HP-diet (0.222) and the NP-diet (0.212) groups, and the lack of the relationship between trypsin specific activity and the T/C ratio (see details in $[12,14]$ ) indicated that the fish were at a similar steady growth phase at sampling at the end of the experiment. 


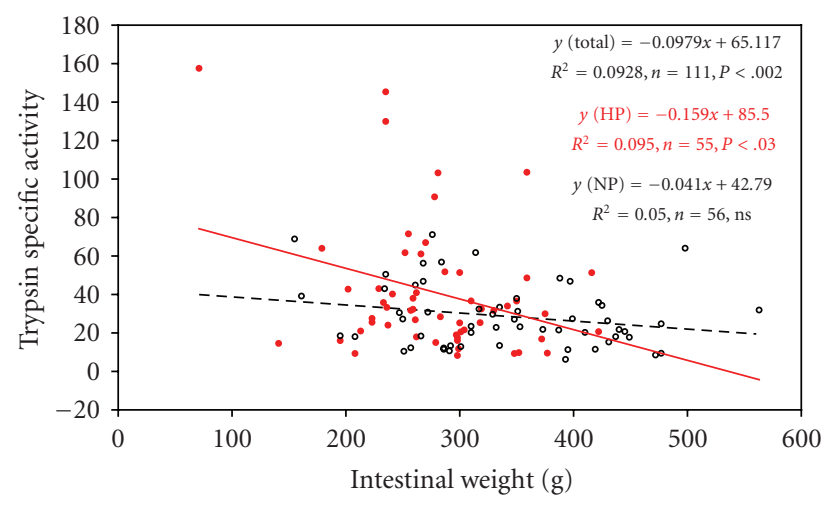

(a)

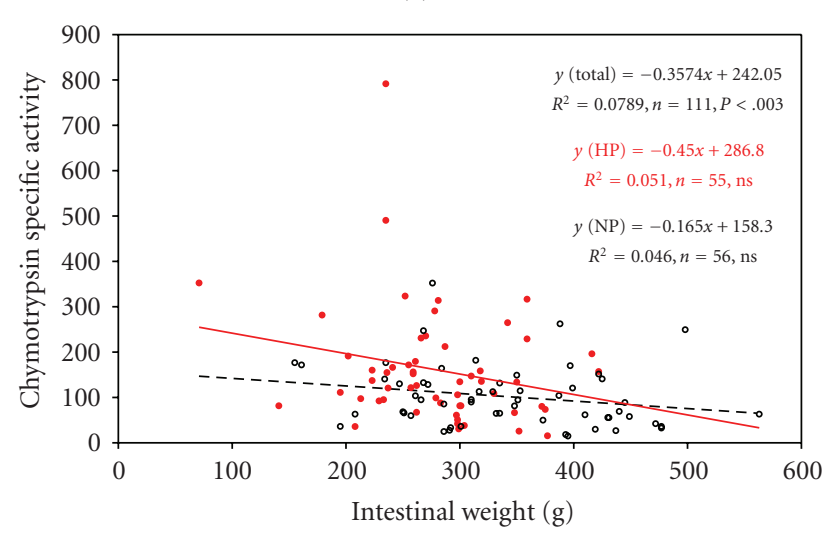

(b)

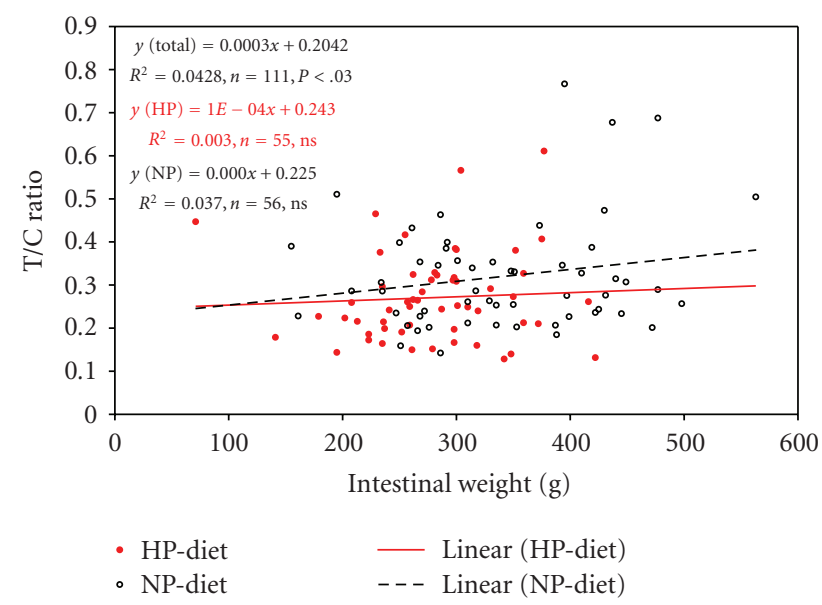

(c)

FIGURE 2: Relationships between intestinal weight with trypsin specific activity $[a]$, chymotrypsin specific activity $[\mathrm{b}]$, and protease activity ratio of trypsin to chymotrypsin (T/C ratio) [c]. The protease specific activities were expressed as $\mu \mathrm{mol} p$-nitroaniline produced $\mathrm{h}^{-1} \mathrm{mg}$ protein ${ }^{-1}$.

3.3. White Muscle and Body Compositions. SGR correlated positively with lipid concentration $(P<.0001)$ in the white muscle, and negatively with moisture $(P<.0001)$ and protein $(P<.02)$ concentrations (Figure 4$)$. This resulted in an inverse relationship between SGR and the composition ratio of protein to lipid ( $\mathrm{P} / \mathrm{L}$ ratio) in the white muscle $(P<$

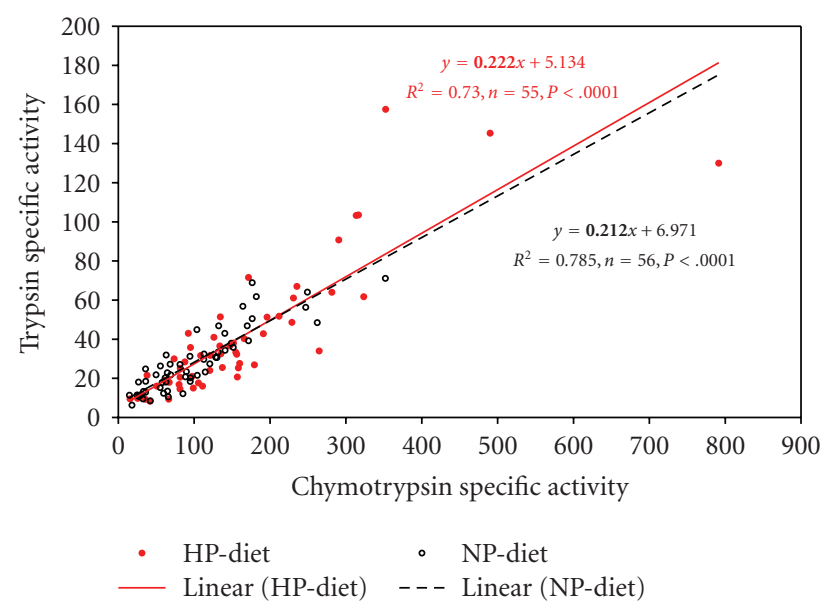

FIGURE 3: Relationships between trypsin (T) and chymotrypsin (C) specific activities showing the slope $\mathrm{T} / \mathrm{C}$ ratios (bold values) of rainbow trout fed normal protein (NP) and high protein (HP) diets at sampling at the end of the experiment in November 2003.

.001; Figure 4). Within each dietary group, the relationships were significant only in the NP-diet fish $(P<.02)$, except for protein concentration that no correlations were observed in both dietary groups (Figure 4).

At successive measurements, protein concentration increased significantly in the white muscle $(P<.0001)$ from November $2002(20.50 \pm 0.08 \%)$ to November 2003 $(24.34 \pm 0.12 \%)$. Lipid concentration $(7.48 \pm 0.19$ vs $7.71 \pm$ $0.08 \%), \mathrm{P} / \mathrm{L}$ ratio $(3.53 \pm 0.09$ vs $3.62 \pm 0.05)$ also increased, albeit insignificant. Moisture concentration, on the other hand, decreased $(P<.0001)$ from November $2002(72.12 \pm$ $0.21 \%)$ to November $2003(70.14 \pm 0.05 \%)$. At the end of the experiment, the moisture concentration in the white muscle was significantly higher in fish fed on HP-diet than those fed on NP-diet $(71.0 \pm 0.2$ vs $69.7 \pm 0.2 \%, P<.0001)$. The concentration of protein $(P<.004)$ and the $\mathrm{P} / \mathrm{L}$ ratio $(P<.0001)$ in the white muscle were also higher and the lipid concentration was lower $(P<.0001)$ in the fish fed the HPdiet than the NP-diet (Table 2). According to the dietary $\mathrm{P} / \mathrm{L}$ ratio levels in the HP (2.1-2.7) and the NP (1.2-1.5) diets (Table 1), rainbow trout at late stage seemed to double the $\mathrm{P} / \mathrm{L}$ ratios in the white muscle (HP-diet fish: $4.44 \pm 0.22$; NPdiet fish: $2.92 \pm 0.14$ ) (Table 2 ) with respect to the $\mathrm{P} / \mathrm{L}$ ratio of the diet consumed.

For whole body composition, SGR also showed positive correlation with lipid concentration $\left(R^{2}=0.09, P<.002\right)$, and negative correlation with protein concentration $\left(R^{2}=\right.$ $0.10, P<.001)$, resulting in an inverse relationship with the $\mathrm{P} / \mathrm{L}$ ratio $\left(R^{2}=0.11, P<.001\right)$. Similar to white muscle composition, whole body concentrations of protein (November 2002: $9.94 \pm 0.14 \%$; November 2003: $16.04 \pm$ $0.06 \%)$, lipid ( $17.98 \pm 0.08$ vs $21.14 \pm 0.16 \%)$, and $\mathrm{P} / \mathrm{L}$ ratio $(0.56 \pm 0.01$ vs $0.77 \pm 0.01)$ increased between successive measurement periods $(P<.0001)$. At the end of the experiment, fish fed on HP-diet had higher concentrations of whole body protein $(16.44 \pm 0.07$ vs $15.65 \pm 0.07 \%)$ and $\mathrm{P} / \mathrm{L}$ 


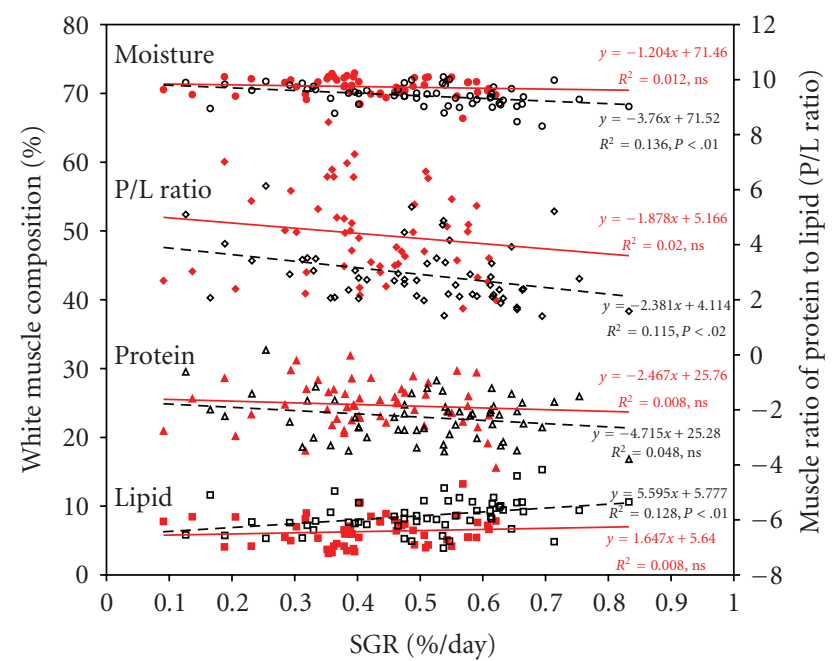

\begin{tabular}{|c|c|c|}
\hline $\mathrm{Hl}$ & $\Delta$ & $\mathrm{HP}$ \\
\hline HP-c & - & HP-diet \\
\hline (HP-diet) & & Linear (HP-diet) \\
\hline NP-diet & $\Delta$ & NP-diet \\
\hline NP-diet & . & NP-diet \\
\hline Linear (NP-diet) & -- & Linear (NP-diet) \\
\hline
\end{tabular}

FIGURE 4: Relationships between specific growth rate (SGR) with white muscle composition and white muscle ratio of protein to lipid ( $\mathrm{P} / \mathrm{L}$ ratio). Regardless of dietary group, the regressions are $y=-4.0641 \mathrm{x}+72.166\left(R^{2}=0.1579, n=111, P<.0001\right.$ for moisture), $y=-5.0925 \mathrm{x}+26.137\left(R^{2}=0.0553, n=111, P<.02\right.$ for protein), $y=6.1719 \mathrm{x}+4.636\left(R^{2}=0.1444, n=111, P<.0001\right.$ for lipid) and $y=-3.4688 \mathrm{x}+5.2283\left(R^{2}=0.1053, n=111\right.$, $P<.001$ for $\mathrm{P} / \mathrm{L}$ ratio).

ratio $(0.82 \pm 0.01$ vs $0.71 \pm 0.01)$, and lower concentration of whole body lipid $(20.15 \pm 0.19$ vs $22.10 \pm 0.17 \%)$ than the NP-diet fish $(P<.0001$; Table 2$)$. Moreover, there was a significant inverse relationship between body $\mathrm{P} / \mathrm{L}$ ratio and the condition factor, regardless of dietary group $(P<.0003$; Figure 5). Within the dietary groups, the relationship was significant only in the NP-diet fish $(P<.004$; Figure 5$)$.

Among different composition parameters studied, white muscle protein concentration was the only factor that significantly correlated with feed efficiency, with a negative relationship $\left(R^{2}=0.11, P<.05\right)$, regardless of dietary type.

\subsection{In Vitro Digestibility and Comparisons between Different} Growth Capacity Groups. Low growth capacity families had lower final weight $(2253 \pm 63 \mathrm{~g})$ than those from medium $(2684 \pm 63 \mathrm{~g})$ and high $(2791 \pm 85 \mathrm{~g})$ growth capacities $(P<$ $.0001)$. Within each growth capacity group, no differences in weight (Figure 6(a)) and the T/C ratio (Figure 6(b)) were observed between the fish fed NP-diet and HP-diet. Feed efficiency was significantly different between the two dietary treatments only in the medium growth capacity families $(P<.01$; Figure 6(c) ). The P/L ratio in the white muscle was higher in the HP-diet than the NP-diet fish in all growth groups $(P<.02$; Figure $6(\mathrm{~d}))$. Interestingly in the high growth families, the white muscle $\mathrm{P} / \mathrm{L}$ ratio of the HP-diet

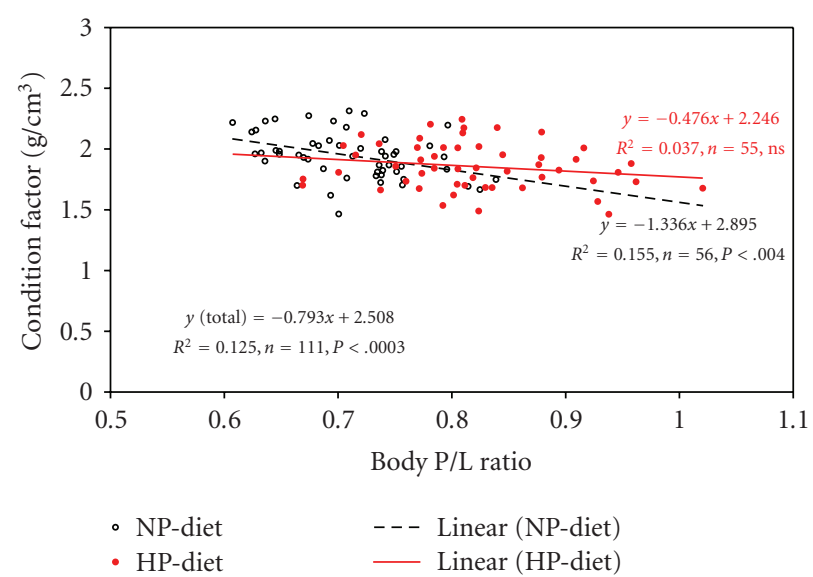

Figure 5: Relationship between body $\mathrm{P} / \mathrm{L}$ ratio and condition factor.

fish increased $80 \%$ more than the NP-diet fish, whereas the increase was only $40 \%$ in the low and medium growth families $(P<.03$; Figure $6(\mathrm{~d}))$.

The digestive ability was different among different growth capacity groups (Figure 7). The enzyme extracts from families with high growth capacity resulted in relatively higher in vitro protein digestibility values for $\mathrm{C}$-diet $(P<$ $.05)$, NP-diet $(P<.05)$, and HP-diet $(P>.05)$ than those from low and medium growth capacity families (Figure 7). Paired comparison indicated significantly higher in vitro protein digestibility of the HP-diet than the C-diet and the NP-diet, regardless of the enzyme extracts used $(P<.0001)$. Within each growth capacity family, a tendency of higher in vitro protein digestibility was observed in the enzyme extracts from fish fed HP-diet, albeit insignificant (Table 2). A significant inverse relationship between in vitro protein digestibility values and SGR $\left(R^{2}=0.18, P<.02\right)$ was observed at maturity in November 2003, regardless of dietary type.

3.5. Analysis of Covariance. The continuous variable white muscle $\mathrm{P} / \mathrm{L}$ ratio was included as covariate in the models in order to study its effect on growth together with fish growth capacity group or family fed on the different diets. Due to class-by-covariate interaction being significant $(P<.05)$, the statistical analysis was performed separately per class. The effects on the growth parameters (final weight, condition factor, and SGR) by growth capacity group and muscle P/Lratio, and by family and muscle P/L-ratio, were studied separately for each dietary group (Table 3 ). Differences in fish growth capacity significantly affected final body weight for both diets but did not affect condition factor and SGR. Family influenced fish SGR for both diets, and the growth of the fish fed on NP-diet was highly affected by family and muscle P/L ratio compared to the HP-diet fish. The results clearly indicated that the differences in fish growth capacity among different families and the level of $\mathrm{P} / \mathrm{L}$ ratio in the white muscle affected fish growth, and their effects varied according to the dietary $\mathrm{P} / \mathrm{L}$ ratio. 


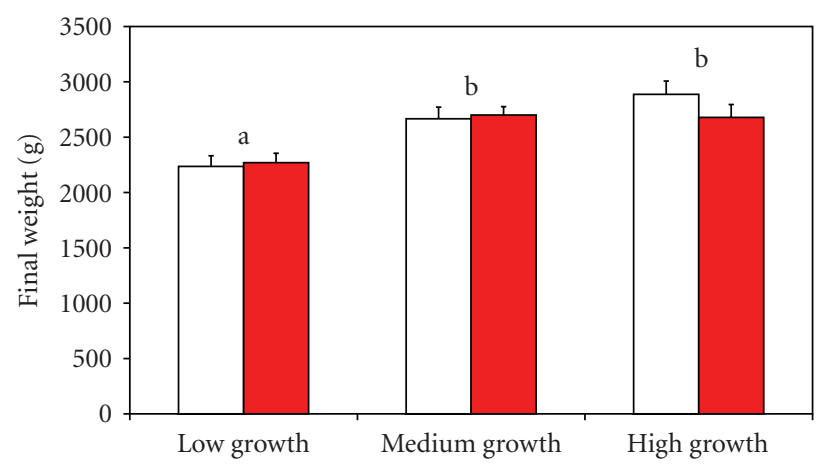

(a)

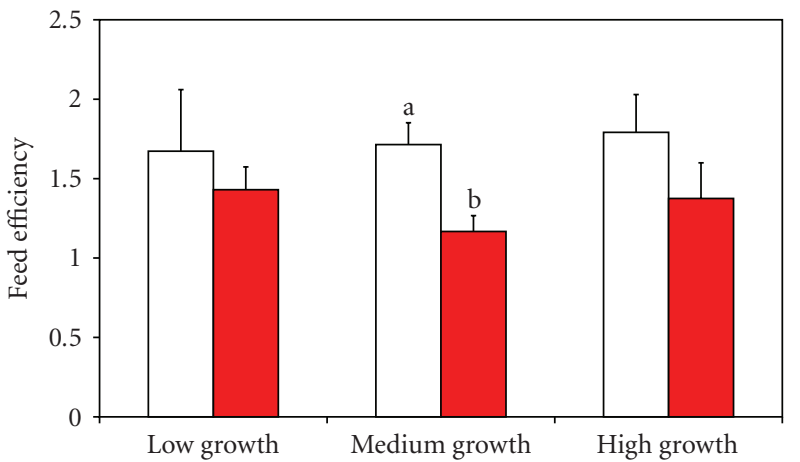

$\square$ NP-diet

$\square$ HP-diet

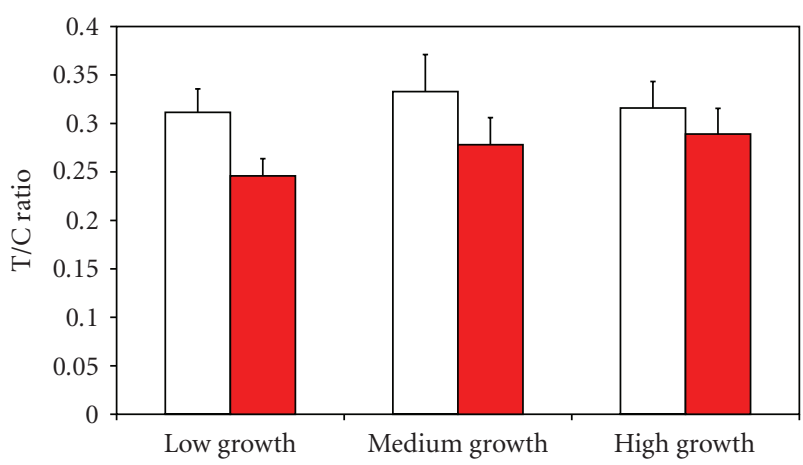

(b)

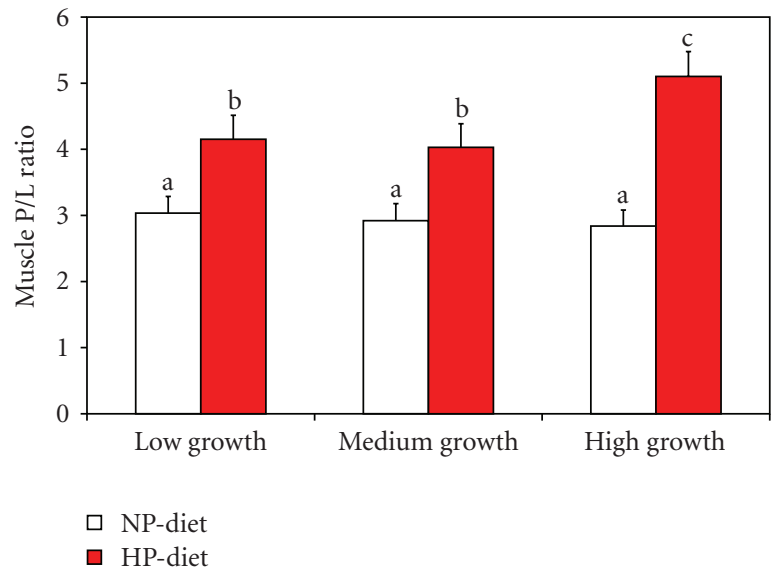

(d)

FIGURE 6: Final body weight [a], protease activity ratio of trypsin to chymotrypsin (T/C ratio) [b], feed efficiency [c], and white muscle composition ratio of protein to lipid (P/L ratio) [d], in groups of rainbow trout with low, medium, and high growth capacity, subdivided according to feeding normal protein (NP) or high protein (HP) diet. The values with different superscripts are significantly different $(P<$ $.05)$.

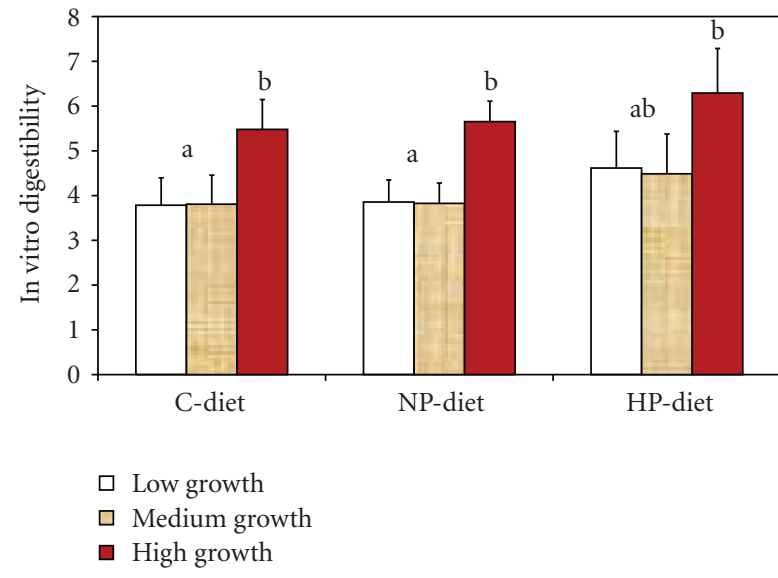

FIGURE 7: In vitro protein digestibility of control (C), normal protein (NP), and high protein (HP) diets, among rainbow trout with low, medium, and high growth capacities. The values with different superscripts are significantly different $(P<.05)$.

In order to study the association between SGR, dietary quality, and digestive abilities of different growth capacity groups, the continuous variable SGR was included as covariate in the models. Similarly, the class-by-covariate interaction was significant $(P<.05)$; thus, the statistical analysis was also performed separately per class. The effects on specific activities of trypsin and chymotrypsin, T/C ratio, and in vitro protein digestibility of diet, by dietary P/L ratio and SGR were studied for each growth capacity group (Table 4). The results indicated an effect of the diet on the $\mathrm{T} / \mathrm{C}$ ratio of the low growth capacity group. There was an indication of the associations between SGR and the specific activities of trypsin and chymotrypsin. Trypsin specific activity was affected in the high growth capacity group, whereas chymotrypsin specific activity was affected in the low growth capacity group. There was an association between SGR and in vitro protein digestibility of the experimental diets in the high growth capacity group.

The analyses of covariance (Tables 3 and 4) indicated the associations between dietary $\mathrm{P} / \mathrm{L}$ ratio, fish digestive ability (trypsin and chymotrypsin specific activity, T/C ratio, in vitro protein digestibility), white muscle $\mathrm{P} / \mathrm{L}$ ratio, growth parameters (fish weight, condition factor, SGR), and variations in growth capacity of different family memberships. 
TABLE 3: Analysis of covariance showing the effects of fish growth capacity (Group) or family and white muscle ratio of protein to lipid (P/L ratio) as covariate, on final weight, condition factor, and specific growth rate (SGR) during September-November 2003. Due to class-bycovariate interaction was significant $(P<.05)$; the statistical analysis was performed separately for the experimental normal protein $(\mathrm{NP})$ and high protein (HP) diets. Probabilities with significant effects are shown by the $P$ values $<.05$ (bold values).

(a)

\begin{tabular}{lcccccrr}
\hline \multirow{2}{*}{ Covariance effect } & \multirow{2}{*}{ df } & \multicolumn{2}{c}{ Final weight } & \multicolumn{2}{c}{ Condition factor } & \multicolumn{2}{c}{ SGR } \\
& & NP & HP & NP & HP & NP & HP \\
\hline Group & 2 & $\mathbf{0 . 0 0 0 3}$ & $\mathbf{0 . 0 0 2 2}$ & 0.4151 & 0.8453 & 0.9703 & 0.7316 \\
Muscle P/L ratio & 1 & $\mathbf{0 . 0 0 1 2}$ & 0.1776 & $\mathbf{0 . 0 0 3 3}$ & 0.7162 & $\mathbf{0 . 0 1 2 5}$ & 0.1689 \\
Family & 15 & $\mathbf{0 . 0 0 3 8}$ & 0.0961 & $<\mathbf{0 . 0 0 0 1}$ & 0.1680 & $\mathbf{0 . 0 0 7 9}$ & $\mathbf{0 . 0 4 6 5}$ \\
Muscle P/L ratio & 1 & $\mathbf{0 . 0 0 3 1}$ & 0.1033 & $\mathbf{0 . 0 0 8 9}$ & 0.4514 & $\mathbf{0 . 0 0 6 7}$ & 0.2924 \\
\hline
\end{tabular}

(b)

\begin{tabular}{lclr}
\hline & & NP & HP \\
\hline \multirow{4}{*}{ Group } & Final weight & $R^{2}=0.389(P<.0001)$ & $R^{2}=0.224(P<.005)$ \\
& Condition factor & $R^{2}=0.186(P<.015)$ & $R^{2}=0.013(P=.883)$ \\
& SGR & $R^{2}=0.117(P=.089)$ & $R^{2}=0.066(P=.321)$ \\
Family & Final weight & $R^{2}=0.606(P<.0005)$ & $R^{2}=0.407(P=.107)$ \\
& Condition factor & $R^{2}=0.725(P<.0001)$ & $R^{2}=0.370(P=.195)$ \\
& SGR & $R^{2}=0.560(P<.0025)$ & $R^{2}=0.467(P<.035)$ \\
\hline
\end{tabular}

\section{Discussion}

Fish growth was affected by dietary $\mathrm{P} / \mathrm{L}$ ratio and by the inherent growth capacity of the fish as well as by white muscle $\mathrm{P} / \mathrm{L}$ ratio (Table 3 ) and by genetic differences in protease digestive ability (Table 4). At late stage, rainbow trout seemed to double their white muscle $\mathrm{P} / \mathrm{L}$ ratio with respect to the dietary $\mathrm{P} / \mathrm{L}$ ratio (Tables 1 and 2 ). Increased dietary protein concentration resulted in elevated protein and reduced lipid concentrations in fish body ([1, 6, 35], current work). In the white muscle, increased dietary protein resulted in elevation of both protein and moisture contents [current work]. Dietary protein concentration is also inversely correlated with protein efficiency ratio and productive lipid value [3]. Increasing dietary protein concentration has been associated with increased muscle protein in salmonids ([35], current work), channel catfish Ictalurus punctatus [2] and grass carp Ctenopharyngodon idella [4], and increased fillet mass and decreased liver and adipose tissue mass in the abdominal cavity in African catfish Clarias gariepinus [7]. In addition, fish fed high protein diets tend to have lower total lipids, triglycerides, and cholesterol in fillets, with higher percentage of polyunsaturated fatty acids (PUFAs) and lower saturated fatty acids [7]. Thus, increasing protein in the diet could result in improved fillet quality. Moreover, HP-diet appeared to promote an increase in length rather than weight during growth (Figures 1 and 5). Our work illustrates the importance of dietary protein level not only on fillet quality but also on skeletal growth. Deformities in juvenile tench (Tinca tinca L.) with significantly elevated whole body lipid have been reported [36]. Increased growth in Atlantic salmon (Salmo salar L.) stimulated by continuous light, which is not caused by increased protein deposition [10] but by increased lipid deposition [13], results in reduced mechanical strength and growth of the vertebrae in Atlantic salmon postsmolts [37]. Thus, stimulating fish growth without concerning with appropriate dietary $\mathrm{P} / \mathrm{L}$ ratio and $\mathrm{P} / \mathrm{L}$ ratio deposition in muscle or body may affect the strength of skeletal growth and cause deformities. Fish growth could be explained not only by body weight but also by body length illustrated as condition factor ([26], current work). Therefore, the conventional study for dietary protein requirement through optimal weight gain in fish (recently, i.e., $[1,3,5,6,8]$ ) should probably instead indicate the effect of optimal dietary protein level on the change of fish growth performance to greater increase in length than weight.

It is interesting to note that fish with different growth capacities [current work] and trypsin phenotypes [14, 38] have different protease digestive abilities. Fish from high growth group had a relatively higher digestive ability for all feed types, compared to those from low and medium growth groups (Figure 7). There were associations between growth and protein digestibility (Table 4 ) as well as between growth and muscle $\mathrm{P} / \mathrm{L}$ ratio (Table 3 ). The high growth capacity families had higher capacity to increase their growth through increase in white muscle protein deposition (Figure 6(d)). In addition, white muscle fibre size was also significantly larger in the high growth capacity fish compared to the medium and low growth capacity groups (pooled data, $P<.01$ ), irrespective of the diet (unpublished data). Furthermore, genetic correlations between percent white muscle area and protein percent in rainbow trout cutlets were very high on both diets, 0.76 in NP-diet and 0.92 in HP-diet groups [39]. These results indicate the advantage of high growth capacity in protein growth performance quality. For more understanding on the effect of dietary $\mathrm{P} / \mathrm{L}$ 
TABle 4: Analysis of covariance showing the effects of dietary P/L ratio level (Diet) and specific growth rate (SGR) during SeptemberNovember 2003 as covariate, on the expression of trypsin and chymotrypsin (expressed as $\mu \mathrm{mol} p$-nitroaniline $\mathrm{h}^{-1} \mathrm{mg} \mathrm{protein}^{-1}$ ), the activity ratio of trypsin to chymotrypsin (T/C ratio), and in vitro protein digestibility (expressed as $\mu \mathrm{mol} D L$-alanine equivalent per mg feed after standardising trypsin activity to $300 \mu \mathrm{mol} p$-nitroaniline produced $\left.\mathrm{h}^{-1} \mathrm{~mL}^{-1}\right)$. Due to class-by-covariate interaction was significant $(P<$ $.05)$; the statistical analysis was performed separately for low $(\mathrm{L})$, medium $(\mathrm{M})$, and high $(\mathrm{H})$ growth capacity groups. Probabilities with significant effects are shown by the $P$ values $<.05$ (bold values).

(a)

\begin{tabular}{lccccccccccccc}
\hline $\begin{array}{l}\text { Covariance } \\
\text { effect }\end{array}$ & df & \multicolumn{3}{c}{ Trypsin } & \multicolumn{4}{c}{ Chymotrypsin } & \multicolumn{3}{c}{ T/C ratio } & \multicolumn{4}{c}{ In vitro digestibility } \\
& & $\mathrm{L}$ & $\mathrm{M}$ & $\mathrm{H}$ & $\mathrm{L}$ & $\mathrm{M}$ & $\mathrm{H}$ & $\mathrm{L}$ & $\mathrm{M}$ & $\mathrm{H}$ & $\mathrm{L}$ & $\mathrm{M}$ & $\mathrm{H}$ \\
\hline Diet & 1 & 0.1796 & 0.3276 & 0.4905 & 0.1033 & 0.3647 & 0.2035 & $\mathbf{0 . 0 4 5 8}$ & 0.4864 & 0.4471 & 0.3286 & 0.6938 & 0.4804 \\
SGR & 1 & 0.1059 & 0.1055 & $\mathbf{0 . 0 3 2 0}$ & $\mathbf{0 . 0 1 7 4}$ & 0.0854 & 0.0905 & 0.9705 & 0.1826 & 0.7424 & 0.4403 & 0.4807 & $\mathbf{0 . 0 4 0 3}$ \\
\hline
\end{tabular}

(b)

\begin{tabular}{llll}
\hline & $\mathrm{L}$ & $\mathrm{M}$ & $\mathrm{H}$ \\
\hline Trypsin & $R^{2}=0.111(P=.163)$ & $R^{2}=0.139(P=.085)$ & $R^{2}=0.173(P<.03)$ \\
Chymotrypsin & $R^{2}=0.205(P<.035)$ & $R^{2}=0.147(P=.078)$ & $R^{2}=0.169(P<.03)$ \\
T/C ratio & $R^{2}=0.131(P=.123)$ & $R^{2}=0.092(P=.213)$ & $R^{2}=0.015(P=.746)$ \\
In vitro digestibility & $R^{2}=0.041(P=.523)$ & $R^{2}=0.016(P=.764)$ & $R^{2}=0.163(P<.035)$ \\
\hline
\end{tabular}

ratio on muscle composition and growth, if possible, other parameters such as cellular growth should be investigated in the future in order to study the insight effect of genetics and nutrition on fish growth. Growth rate was correlated with feed intake but was not correlated with feed efficiency (FE), as FE reduces when consumption increases beyond a threshold level $[11,21]$. The inverse relationship observed between FE and white muscle protein concentration (not with body protein concentration) was probably due to a limited capacity to deposit muscle protein. Differences in FE have been associated with variations in the levels of total free amino acids in the plasma and white muscle as well as in the ratio of essential to nonessential free amino acids, and with variations in free hydroxyproline and RNA concentrations in the white muscle [18]. In addition, relationships have been observed between T/C ratio in the pyloric caeca and concentration ratios of essential to nonessential free amino acids in plasma and white muscle as well as between $\mathrm{T} / \mathrm{C}$ ratio with free hydroxyproline and RNA concentrations in the white muscle [10]. Moreover, a significant positive relationship between $\mathrm{FE}$ and $\mathrm{T} / \mathrm{C}$ ratio has been observed in fish fed diets varying in dietary quality $[11,16]$. The current work further emphasises these associations between FE, T/C ratio, and levels of protein and lipid utilisation for deposition in the white muscle. High protein concentration in the white muscle of maturing rainbow trout, as high as $30 \%$ with $24 \pm$ $0.1 \%$ on total average observed in the current study (Table 2 ) compared to normal values of $15-20 \%$ reported [40], was probably due to complete solubilisation of protein by using the newly developed method, as higher protein solubility resulted in higher percentage protein measurements. The high white muscle protein concentration might as well be a characteristic of maturing salmonids, as it has also been observed in maturing Atlantic salmon [11], which is probably due to mobilisation of muscle lipid as energy for reproduction. The highest muscle protein concentration observed in maturing Atlantic mackerel (Scomber scombrus
L.) was only $24 \%$ with $14 \pm 1 \%$ on average [12]. Whilst it was $20 \%$ with $17 \pm 0.1 \%$ on average in Atlantic salmon of about $250 \mathrm{~g}$ [11], and $25 \%$ with $21 \pm 0.1 \%$ on average in rainbow trout of about $1 \mathrm{~kg}$ [current work]. During the final year of the experiment, the composition of body and white muscle successively changed with concentration of protein increasing and moisture concentration decreasing.

Higher dietary protein induced increases in protease specific activities of trypsin and chymotrypsin in the pyloric caeca (Table 2). In a previous experiment using the same feed but varying rearing conditions, both trypsin specific activity and $\mathrm{T} / \mathrm{C}$ ratio were related to growth rate $[10]$, whereas in the current work varying in feed quality, only the T/C ratio was positively associated with growth rate (Table 2 ). Thus, the $\mathrm{T} / \mathrm{C}$ ratio has an effect on growth efficiency independent of the specific activity level of the proteases. This has also been observed in Atlantic salmon [32] and gene manipulated fish $[10,41]$. A reduction in $\mathrm{T} / \mathrm{C}$ ratio in the $\mathrm{HP}$-diet fish, relative to NP-diet fish, caused by a greater increase in the activity of chymotrypsin over trypsin confirmed a reduction in growth rate (Table 2 ). This has been reported in several works [11, $12,14,18,32]$. The confirmation is also strengthened by the observed associations between trypsin specific activity and high growth and between chymotrypsin specific activity and low growth (Table 4). In vitro protein digestibility values of different diets (Figure 7 and Table 4) were influenced by fish growth capacity and the levels of protease expression in fish enzyme extracts. The in vitro protein digestibility of diets has been affected by genetic differences in trypsin phenotypes $[33,38]$, and different trypsin phenotypes affected variations in the protease activity expression levels [14] and FE [42]. At sampling in November 2003, the fish were at a similar steady growth phase showing by similar slope T/C ratio (Figure 3) (details in [32]) and no correlation between trypsin specific activity and the $\mathrm{T} / \mathrm{C}$ ratio (data not shown) (details in $[12,14])$. At steady growth phase, utilization of protein for deposition and growth would be reduced 
to a maintenance level that should be steady irrespective of diet. This is confirmed by the observed higher rate of nitrogen excretion in the HP-diet fish than the NP-diet fish with similar absolute nitrogen retention between the two dietary groups at the end of the experiment (D. Tobin, personal communication). If the fish had been at a growing phase, lower nitrogen excretion per $\mathrm{kg}$ of fish growth in rainbow trout fed diet with higher protein content [43] and increased nitrogen retention with increased protein deposition [35] would have been observed in the HPdiet fish. Growth status of the fish is very important for interpreting biological parameters. At present, the slope T/C ratio and the relationship between trypsin specific activity and the T/C ratio in the pyloric caeca seem to be the only indicators available for predicting relative growth level and growth status of the fish at sampling, respectively, without knowing fish history see $[12,14,32]$. Our results suggest the association between the diet dependent in vitro protein digestibility value and protein growth in fish, whereas the $\mathrm{T} / \mathrm{C}$ ratio is associated with fish growth regardless of protein or lipid growth. In vitro digestibility by protein digestion is the key factor for diet quality, not only in carnivores but also in herbivores where carbohydrate digestion (the second important digestion factor in herbivores after protein digestion) is also related to dietary protein levels $[19,20]$ while lipid digestion is not related to any diet quality [19]. A high protein diet may limit feed efficiency, weight, and growth rate of the fish, as they become mature. Analyses of covariance also indicate the associations among genetic differences in protease digestive efficiency, the dietary P/L ratio, and fish growth (Table 4), and showing the influence of white muscle P/L ratio on the SGR (Table 3).

The T/C ratio (directly calculated from the enzyme activities) and the slope T/C ratio (obtained as shown in Figure 3 ) are the suitable factors for comparison of growth efficiency between fish groups over a period of 1-2 months and at sampling, respectively, regardless of either protein or lipid growth or the protease specific activity levels ([10$12,14,18,32]$, current work). It is important to calculate the $\mathrm{T} / \mathrm{C}$ ratio and slope $\mathrm{T} / \mathrm{C}$ ratio in the pyloric caeca for comparison instead of using trypsin specific activity alone. If fish are needed alive, biopsy of pyloric caeca could be performed [44], or the T/C ratio in faeces could also be used for comparison of digestive and growth efficiency but not for predicting growth status [11]. Most observed relationships between key factors have very low correlation coefficients $[10,14,45]$, current work). This is due to their indirect interaction in a series of biological mechanisms. The phenomenon is common, as many factors being involved in biological processes.

The dietary protein concentration of $\geq 50 \%$ used in this work is not actually practical in the production of large fish due to high cost. It was purely intended to act as a challenge environment to optimising the genetic response of traits such as protein and growth efficiency in salmonids [21, 22, 27]. However, as a long-term study, it has enabled us to investigate the effect of dietary protein on skeletal growth (length), which is important knowledge for future production of fish with high growth performance quality [32] as well as for future growth study in natural ecosystems where protein deposition is the main cause [12].

\section{Conclusions}

Dietary $\mathrm{P} / \mathrm{L}$ ratio affected the level of digestion and utilisation of protein and lipid for deposition in the white muscle that influenced feed efficiency and growth of the fish. Muscle protein concentration increased between successive measurement periods, and older larger fish had higher concentration than younger smaller fish. Fish with higher growth capacity had better chance to deposit higher protein. Protein deposition was associated more with body length than body weight, resulting in lower condition factor. Fish with higher protein growth had lower feed efficiency and SGR during maturation. Genetic effect of protease digestive efficiency on fish growth is evident $([14,38]$, current work). In vitro protein digestibility of experimental diets using fish crude enzyme extract and standardised by trypsin activity is useful not only for comparison and prediction of biological quality of different diets $[11,16]$, but also for comparison of genetic differences in fish digestive efficiency ([33], current work) and fish growth capacity [current work]. Specific activity levels of trypsin and chymotrypsin were related to dietary protein concentrations. The $\mathrm{T} / \mathrm{C}$ ratio and slope $\mathrm{T} / \mathrm{C}$ ratio were related to growth efficiency over a period of 1-2 months and at sampling, respectively, regardless of protein or lipid growth or the specific activity levels of the two enzymes $([10,32]$, current work). A relatively higher increase in chymotrypsin over trypsin activity, resulting in lower $\mathrm{T} / \mathrm{C}$ ratio, affected a reduction in growth rate and indicated the associations between trypsin specific activity and high growth and between chymotrypsin specific activity and low growth ([12, 14, 32], current work). The associations of all parameters studied by the analyses of covariance (Tables 3 and 4 ) indicate the influences of both external (dietary P/L ratio) and internal (variations in inherent growth capacity of different family memberships) factors on fish growth, through biological changes in digestive ability (trypsin and chymotrypsin specific activity, T/C ratio, in vitro protein digestibility) and white muscle $\mathrm{P} / \mathrm{L}$ ratio. High dietary protein results in similar weight, but higher growth in length (skeletal growth) and better fillet quality that would nutritionally benefit to consumers, compared to high dietary lipid. The work shows the advantage of using the unique combination of the practical methods for growth performance quality study that could be performed in any uncontrolled condition, such as in the natural ecosystem where protein deposition is important and study on biological responses to environmental changes for survival has been ignored. It also provides more knowledge on dietary protein affecting skeletal growth as well as the interaction between genetics and nutrition affecting digestive ability and growth performance quality of the animal.

\section{Acknowledgments}

The authors thank T. Paananen and K. Manninen, the staff at the Finnish Game and Fisheries Research Institute (Tervo, 
Finland), H. Wahlroos (then at MTT Agrifood Research Finland) for their contributions and taking care of the fish, and L. Dyrhovden (Institute of Marine Research, Norway) for assisting in collecting samples. The work was financially supported by the Commission of the European Communities, Quality of Life and Management of Living Resources Programme. It was a part of the EU-project Q5RS-20010994, protein and growth efficiency in salmonid selection (PROGRESS), where the authors would like to thank K. Ruohonen (then at Finnish Game and Fisheries Research Institute, Turku, Finland), E. Mäntysaari and A. Kause (MTT Agrifood Research Finland, Jokioinen, Finland), D. F. Houlihan and S.A.M. Martin (University of Aberdeen, UK), and A. Kiessling (then at the Institute of Marine Research, Norway) for their cooperations. The project was coordinated by the Finnish Game and Fisheries Research Institute, Finland. The University of Bergen, Norway, was the subcontractor of the Institute of Marine Research, Norway. The paper does not necessarily reflect its views and in no way anticipates the Commission's future policy in this area.

\section{References}

[1] S. S. Giri, S. K. Sahoo, A. K. Sahu, and P. K. Meher, "Effect of dietary protein level on growth, survival, feed utilisation and body composition of hybrid Clarias catfish (Clarias batrachus $\times$ Clarias gariepinus)," Animal Feed Science and Technology, vol. 104, no. 1-4, pp. 169-178, 2003.

[2] L. S. Jackson, E. H. Robinson, M. H. Li, W. R. Wolters, and D. A. McKee, "Restricted and satiate feeding of two genetically isolated strains of Juvenile channel catfish Ictalurus punctatus reared on $28 \%$ and $32 \%$ protein diets," Journal of the World Aquaculture Society, vol. 34, no. 4, pp. 478-486, 2003.

[3] S.-D. Yang, T.-S. Lin, C.-H. Liou, and H.-K. Peng, "Influence of dietary protein levels on growth performance, carcass composition and liver lipid classes of Juvenile Spinibarbus hollandi (Oshima)," Aquaculture Research, vol. 34, no. 8, pp. 661-666, 2003.

[4] M. A. Khan, A. K. Jafri, and N. K. Chadha, "Growth, reproductive performance, muscle and egg composition in grass carp, Ctenopharyngodon idella (Valenciennes), fed hydrilla or formulated diets with varying protein levels," Aquaculture Research, vol. 35, no. 13, pp. 1277-1285, 2004.

[5] K.-W. Kim, X. J. Wang, K. M. Han, S. C. Bai, and J.-C. Kang, "Optimum dietary protein level and protein-to-energy ratio for growth of Juvenile Korean rockfish Sebastes schlegeli," Journal of the World Aquaculture Society, vol. 35, no. 3, pp. 305-314, 2004.

[6] Z. Luo, Y. J. Liu, K. S. Mai, L. X. Tian, D. H. Liu, and X. Y. Tan, "Optimal dietary protein requirement of grouper Epinephelus coioides Juveniles fed isoenergetic diets in floating net cages," Aquaculture Nutrition, vol. 10, no. 4, pp. 247-252, 2004.

[7] F. Matter, S. Peganova, and K. Eder, "Lipid concentrations of fillets, liver, plasma and lipoproteins of African catfish, Clarias gariepinus (Burchell 1822), fed diets with varying protein concentrations," Journal of Animal Physiology and Animal Nutrition, vol. 88, no. 7-8, pp. 275-287, 2004.

[8] G. Meyer and D. M. Fracalossi, "Protein requirement of jundia fingerlings, Rhamdia quelen, at two dietary energy concentrations," Aquaculture, vol. 240, no. 1-4, pp. 331-343, 2004.
[9] S. N. Jana, S. K. Garg, U. K. Barman, A. R. T. Arasu, and B. C. Patra, "Effect of varying dietary protein levels on growth and production of Chanos chanos (Forsskal) in inland saline groundwater: laboratory and field studies," Aquaculture International, vol. 14, no. 5, pp. 479-498, 2006.

[10] J. Sunde, G. L. Taranger, and K. Rungruangsak-Torrissen, "Digestive protease activities and free amino acids in white muscle as indicators for feed conversion efficiency and growth rate in Atlantic salmon (Salmo salar L.)," Fish Physiology and Biochemistry, vol. 25, no. 4, pp. 335-345, 2001.

[11] K. Rungruangsak-Torrissen, "Digestive efficiency, growth and qualities of muscle and oocyte in Atlantic salmon (Salmo salar L.) fed on diets with krill meal as an alternative protein source," Journal of Food Biochemistry, vol. 31, no. 4, pp. 509540, 2007.

[12] K. Rungruangsak-Torrissen and J. E. Fosseidengen, "Effect of artificial feeding on digestive efficiency, growth and qualities of muscle and oocyte of maturing Atlantic mackerel (Scomber scombrus L.)," Journal of Food Biochemistry, vol. 31, no. 6, pp. 726-747, 2007.

[13] F. Oppedal, A. Berg, R. E. Olsen, G. L. Taranger, and T. Hansen, "Photoperiod in seawater influence seasonal growth and chemical composition in autumn sea-transferred Atlantic salmon (Salmo salar L.) given two vaccines," Aquaculture, vol. 254, no. 1-4, pp. 396-410, 2006.

[14] K. Rungruangsak-Torrissen, R. Moss, L. H. Andresen, A. Berg, and R. Waagbø, "Different expressions of trypsin and chymotrypsin in relation to growth in Atlantic salmon (Salmo salar L.)," Fish Physiology and Biochemistry, vol. 32, no. 1, pp. 7-23, 2006.

[15] I. D. McCarthy, D. F. Houlihan, C. G. Carter, and K. Moutou, "Variation in individual food consumption rates of fish and its implications for the study of fish nutrition and physiology," Proceedings of the Nutrition Society, vol. 52, no. 3, pp. 427-436, 1993.

[16] K. Rungruangsak-Torrissen, A. Rustad, J. Sunde, et al., "In vitro digestibility based on fish crude enzyme extract for prediction of feed quality in growth trials," Journal of the Science of Food and Agriculture, vol. 82, no. 6, pp. 644-654, 2002.

[17] K. Rungruangsak-Torrissen and A. Sundby, "Protease activities, plasma free amino acids and insulin at different ages of Atlantic salmon (Salmo salar L.) with genetically different trypsin isozymes," Fish Physiology and Biochemistry, vol. 22, no. 4, pp. 337-347, 2000.

[18] J. Sunde, S. A. Eiane, A. Rustad, et al., "Effect of fish feed processing conditions on digestive protease activities, free amino acid pools, feed conversion efficiency and growth in Atlantic salmon (Salmo salar L.)," Aquaculture Nutrition, vol. 10, no. 4, pp. 261-277, 2004.

[19] M. Areekijseree, A. Engkagul, S. Kovitvadhi, U. Kovitvadhi, A. Thongpan, and K. Rungruangsak-Torrissen, "Development of digestive enzymes and in vitro digestibility of different species of phytoplankton for culture of early Juveniles of the freshwater pearl mussel, Hyriopsis (Hyriopsis) bialatus Simpson, 1900," Invertebrate Reproduction \& Development, vol. 49, no. 4, pp. 255-262, 2006.

[20] P. Supannapong, T. Pimsalee, T. A-Komol, et al., "Digestive enzymes and in-vitro digestibility of different species of phytoplankton for culture of the freshwater pearl mussel, Hyriopsis (Hyriopsis) bialatus," Aquaculture International, vol. 16, no. 5, pp. 437-453, 2008. 
[21] A. Kause, D. Tobin, A. Dobly, et al., "Recording strategies and selection potential of feed intake measured using the X-ray method in rainbow trout," Genetics Selection Evolution, vol. 38, no. 4, pp. 389-409, 2006.

[22] A. Kause, D. Tobin, D. F. Houlihan, et al., "Feed efficiency of rainbow trout can be improved through selection: different genetic potential on alternative diets," Journal of Animal Science, vol. 84, no. 4, pp. 807-817, 2006.

[23] National Research Council, Nutrient Requirements of Fish, National Academy Press, Washington, DC, USA, 1993.

[24] C. Y. Cho, "Feeding systems for rainbow trout and other salmonids with reference to current estimates of energy and protein requirements," Aquaculture, vol. 100, no. 1-3, pp. 107123, 1992.

[25] E. D. Houde and R. C. Schekter, "Growth rate, rations and cohort consumption of marine fish larvae in relation to prey concentration," Rapports et Procès-Verbaux des Réunions du Conseil International pour l'Exploration de la Mer, vol. 178, pp. 441-453, 1981.

[26] G. P. Busacker, I. R. Adelman, and E. M. Goolish, "Growth," in Methods for Fish Biology, C. B. Screck and P. B. Moyle, Eds., pp. 363-387, American Fisheries Society, Bethesda, Md, USA, 1990.

[27] D. Tobin, A. Kause, E. A. Mäntysaari, et al., "Fat or lean? The quantitative genetic basis for selection strategies of muscle and body composition traits in breeding schemes of rainbow trout (Oncorhynchus mykiss)," Aquaculture, vol. 261, no. 2, pp. 510$521,2006$.

[28] N. Losnegård, B. Bøe, and T. Larsen, Undersøkelse av ekstrakssjonsmidler av fett, Fiskeridirektoratets Sentrallaboratorium, Bergen, Norway, 1979.

[29] Ø. Lie, R. Waagbø, and K. Sandnes, "Growth and chemical composition of adult Atlantic salmon (Salmo salar) fed dry and silage-based diets," Aquaculture, vol. 69, no. 3-4, pp. 343353, 1988.

[30] R. Christiansen, J. Glette, Ø. Lie, O. J. Torrissen, and R. Waagbø, "Antioxidant status and immunity in Atlantic salmon, Salmo salar L., fed semi-purified diets with and without astaxanthin supplementation," Journal of Fish Diseases, vol. 18, no. 4, pp. 317-328, 1995.

[31] O. H. Lowry, N. J. Rosebrough, A. L. Farr, and R. J. Randall, "Protein measurement with Folin phenol reagent," Journal of Biological Chemistry, vol. 193, no. 1, pp. 265-275, 1951.

[32] K. Rungruangsak-Torrissen, J. Sunde, A. E. Berg, U. Nordgarden, P. G. Fjelldal, and F. Oppedal, "Digestive efficiency, free amino acid pools and quality of growth performance in Atlantic salmon (Salmo salar L.) affected by light regimes and vaccine types," Fish Physiology and Biochemistry, vol. 35, no. 2, pp. 255-272, 2009.

[33] M. Bassompierre, T. H. Ostenfeld, E. McLean, and K. Rungruangsak-Torrissen, "In vitro protein digestion, and growth of Atlantic salmon with different trypsin isozymes," Aquaculture International, vol. 6, no. 1, pp. 47-56, 1998.

[34] A. I. Ihekoronye, "Rapid in vitro enzymatic predictive model for the in vivo digestibility of food proteins," Journal of Food Technology, vol. 21, no. 1, pp. 81-87, 1986.

[35] P. A. Azevedo, S. Leeson, C. Y. Cho, and D. P. Bureau, "Growth and feed utilization of large size rainbow trout (Oncorhynchus mykiss) and Atlantic salmon (Salmo salar) reared in freshwater: diet and species effects, and responses over time," Aquaculture Nutrition, vol. 10, no. 6, pp. 401-411, 2004.
[36] J. Wolnicki, L. Myszkowski, M. Korwin-Kossakowski, R. Kamiński, and L. A. Stanny, "Effects of different diets on Juvenile tench, Tinca tinca (L.) reared under controlled conditions," Aquaculture International, vol. 14, no. 1-2, pp. 8998, 2006

[37] P. G. Fjelldal, U. Nordgarden, A. Berg, et al., "Vertebrae of the trunk and tail display different growth rates in response to photoperiod in Atlantic salmon, Salmo salar L., post-smolts," Aquaculture, vol. 250, no. 1-2, pp. 516-524, 2005.

[38] K. Rungruangsak-Torrissen and R. Male, "Trypsin isozymes: development, digestion and structure," in Seafood Enzymes: Utilization and Influence on Postharvest Seafood Quality, N. F. Haard and B. K. Simpson, Eds., pp. 215-269, Marcel Dekker, New York, NY, USA, 2000.

[39] A. Kause, L. H. Stien, K. Rungruangsak-Torrissen, O. Ritola, K. Ruohonen, and A. Kiessling, "Image analysis as a tool to facilitate selective breeding of quality traits in rainbow trout," Livestock Science, vol. 114, no. 2-3, pp. 315-324, 2008.

[40] M. Jobling, "Nutrient partitioning and the influence of food composition on body composition," in Food Intake in Fish, D. F. Houlihan, T. Boujard, and M. Jobling, Eds., pp. 354-375, Blackwell Science, Oxford, UK, 2001.

[41] P. U. Blier, H. Lemieux, and R. H. Devlin, "Is the growth rate of fish set by digestive enzymes or metabolic capacity of the tissues? Insight from transgenic coho salmon," Aquaculture, vol. 209, no. 1-4, pp. 379-384, 2002.

[42] K. Rungruangsak-Torrissen, G. M. Pringle, R. Moss, and D. F. Houlihan, "Effects of varying rearing temperatures on expression of different trypsin isozymes, feed conversion efficiency and growth in Atlantic salmon (Salmo salar L.)," Fish Physiology and Biochemistry, vol. 19, no. 3, pp. 247-255, 1998.

[43] D. Lanari and E. D'Agaro, "Effects of changes in dietary (DP/DE ratio during the growing phase on growth performance and carcass composition of rainbow trout (Oncorhynchus mykiss, Walbaum)," Aquaculture International, vol. 10, no. 5, pp. 421-432, 2002.

[44] K. R. Torrissen, "Genetic variation in growth rate of Atlantic salmon with different trypsin-like isozyme patterns," Aquaculture, vol. 93, no. 4, pp. 299-312, 1991.

[45] H. Lemieux, P. Blier, and J.-D. Dutil, "Do digestive enzymes set a physiological limit on growth rate and food conversion efficiency in the Atlantic cod (Gadus morhua)?" Fish Physiology and Biochemistry, vol. 20, no. 4, pp. 293-303, 1999. 